NotícIAS 


\section{Coleção Marcello Tupynambá}

No ano passado, o Arquivo IEB-USP recebeu a Coleção Marcello Tupynambá. Doada por seu bisneto, Marcelo Tupynambá Leandro, ela reúne cerca de 245 documentos, sendo a maioria composta de partituras manuscritas avulsas e encadernadas, partituras impressas e editadas, além de um significativo conjunto de fotografias. Esta nova coleção dialoga com os fundos Mário de Andrade, Camargo Guarnieri e Francisco Mignoni, vindo complementar aspectos de relevo no tocante à produção musical da cidade de São Paulo, especialmente na primeira metade do século XX. Dentre as várias áreas de interesse contempladas pela Coleção Marcello Tupynambá, destacam-se a música brasileira, a música popular e o teatro de revista.

Marcello Tupynambá foi o pseudônimo adotado pelo músico Fernando Álvares Lobo, no tempo em que essa atividade não era vista com bons olhos. Nascido em Tietê, a 29 de maio de 1889, faleceu em São Paulo, a 4 de julho de 1953. Filho do casal Eduardo Álvares Lobo, maestro, e de D. Maria Rodrigues de Azevedo Lobo, professora, na sua família também se destaca a figura do tio, o maestro e compositor Elias Álvares Lobo, de quem o Arquivo IEB-USP também possui uma coleção documental. Durante a sua carreira, Tupynambá compôs mais de 1200 melodias, das quais seiscentas foram impressas e gravadas.

Os documentos dessa valiosa coleção podem ser consultados no Arquivo IEB-USP, que está aberto de segunda à sexta-feira, das 8 às $16 \mathrm{~h} 45$. 